\title{
WOMAN IS AN AFFLICT IN THE CIRCLE OF REASON
}

\begin{tabular}{|l|}
\hline R Sujata Rani \\
MA,MA,MPhil,(Ph.D) \\
Assistant Professor \\
Paladugu Parvathi Devi College of Engg. \& Tech. \\
Surampalli, Vijayawada \\
sujatharani.r@gmail.com, sujatha_1971@yahoo.co.in
\end{tabular}

\begin{abstract}
Amitav Ghosh was born in Calcutta now called Kolkata on 11 July 1956. He grew-up and was educated in different places such as Bangladesh, Sri Lanka, Iran, Egypt, India and the United Kingdom. He started his career as a journalist at the Indian Express newspaper in New Delhi. After completing his Ph.D, he decided to settle down as a writer. In a short span of time, he became one of the well-known Indian writers in English. He wrote fiction and non-fiction as well as some essays. He mainly chooses historical background incidents. The Circle of the Reason was his very first novel, which was published in 1986. The novel secured international acclaim in the literary circles. The Circle of Reason has been divided into three parts: Reason, Passion and Death (Satwa, Rajas and Tamas).

The present paper is projected on the problems, responsibilities and household tasks, of woman in The Circle of Reason. It demonstrated how the woman was affected by the war.
\end{abstract}

Key Words: desire, lust, attachment, movement, destruction, ignorance and striving

Amitav Ghosh has brought into The Circle of Reason, various disciplines such as history, sociology, politics, philosophy, psychology, literature, migration etc. The writer renounces the institutionalized version of history. Creation, desire, lust, attachment, movement, striving, destruction, madness, ignorance and innocence caused to problem in every woman's character in The Circle of Reason. The novel, The Circle of Reason, has been divided into three parts: Reason, Passion and Death (Satwa, Rajas and Tamas). The story begins with the arrival of Nachiketa Bose, the protagonist, in search of shelter at his uncle, Balaram and aunt Toru-debi after the passing away of his parents in a car accident. $\mathrm{He}$ is eight when he reaches Lalpukur. Lalpukur is a peaceful remote area in Calcutta. Toru-debi is a childless woman. She only knows about sewing machine. Machine is her world. At the time of Balaram working as a journalist in Amrita Bazaar Patrika, she has maintained her family and passed her days with sewing machine. 'Childless herself, Torudebi knew nothing of children. Children inhabited another world. A world without sewing machines. They neither hemmed, 
nor chain-stitched, nor cross-stitched, nor quilted. What did they do?'(TCR 6) Later her husband gets back to village, there he started too many conflicts in the peaceful village. Balaram to calculate the heads of the village people with a tool, to assess their future, it is called phrenology. $\mathrm{He}$ tries to measure his wife's head but she doesn't accept his mechanism. 'Toru-debi had never permitted Balaram to examine her skull, and never would, but for years Balaram had carefully observed her head in the mornings when her hair clung to her head after her bath, and as far as he was concerned he knew it as intimately as one of his plastic demonstration skulls.'(TCR 13) Balaram always thinks of making Lalpukur a knowledge hub with clean and green surroundings. But his excessive enthusiasm, obstinacy, one-sidedness and poking into the matters of others create a lot of disturbance in the small and peaceful village and his wife Toru-debi. $\mathrm{He}$ becomes a bundle of contradictions not only in the village but also in his family.

Balaram, goes by the book Life of Pasteur to sustain the reason all through. He understands that science is completely based on the theory of reason and result. He firmly believes that Luis Pasteur had been able to combine the rational temperament with the ordinary things that would better the quality of life. Toru-debi understands the book is caused too many problems. '...Listen, you. If I ever hear again that you're gone out of this house with those instruments, there'll be nothing left in your study. Those books have cursed you, and now you're trying to drag me down with you. But I won't go.'(TCR 26) Balaram becomes a spoilsport in the celebrations of Budheb Roy's school. This has strained the relation between Balaram and Budheb Roy. When Torudebi heard about her husband cause to spoil the celebration she has taken responsibility to solve the problem. But she doesn't know how to solve it, she knows only sewing machine because she thinks the matter will be solved by stitching the blouse of Budheb Roy's wife Parboti. 'First I'll say, Parboti, where have you been? Haven't seen you, haven't seen you for months. And all that. Then: Such nice coconuts ... Then: What about some blouses? I'll make you some blouses. Six.'(TCR 100)

His strong bent of mind towards reason drives Balaram to start a school with a different ideology. He gave a section to his wife. But she cannot understand her husband's will, she thinks it is also creates another problem in the peaceful village. Balaram gave her 
ELK

Asia Pacific Journals

stitching section. 'Balaram was still left with the problem of persuading Toru-debi to teach in the school. Twice he began to explain to her, but both times his courage failed him and he ended in stammering confusion.'(TCR 119) Toru-debi suffered a lot as an innocent lady tries to control all problems which were made by her husband.

Meanwhile Sombhu Debnath brings Parboti with him to Toru-debi's home she innocently thinks she comes for blouses. Poor lady does not understand that war is caused to creating problems. '... she whispered into Maya's ear. She wants the blouses.'(TCR 145) She thinks sewing machine solves the problems. 'She says the machine is about to save us: she's finished four and she's halfway through the fifth.'(TCR 156) When the problems were raised in the village by her husband, she thinks machine is dead. 'She stood up and put the sewing machine in his arms. Throw it into the pond, she said, It's dead.'(TCR 159)

Nonder-ma is a servant-maid in Balaram's home and also widow. 'Nonderma hobbled out of the kitchen mumbling toothlessly, bent almost double, no more than a few withered bones, with her widow's white homespun wrapped so carelessly around her that her dugs flapped
ELK Asia Pacific Journals - Special Issue ISBN: 978-81-930411-1-6

outside, hanging down to her shrunken waist.' (TCR 5) Though she has done all works in Balaram's home she was paid fewer amounts from his family. When Alu entered in Balaram's home, she has taken responsibility of him. It is an extra burden to her. 'Everything in this house, Nonderma often muttered, falls to me-the cooking, sweeping, washing, everything, and now the boy, too. And all for what? A few rupees, hardly enough for a sari a year.' (TCR 7)

Maya Debnath, weaving family girl, is another servant-maid in Balaram's home. She is no bigger than Alu. She also lost her mother in her early age. Her father Sombhu Debnath is drunker and brother Rakhal is no thinking about family. In that condition, she has taken her family responsibility and joins as a servant-maid in Balaram's home. 'Maya Debnath, no bigger than Alu, who actually did most of the washing and sweeping, walking over every day from her father's huts beyond the bamboo forest.'(TCR 7) Shombhu Debnath, who teaches Alu the art of weaving, is a lowly man in Lalpukur. It is, therefore, not respectable to learn weaving from him. When Alu feels difficulty in weaving Maya Debnath helps his teaching weaving and tries to encourage him to go back to 
his home. 'Maya cut it from the cloth beam for him. You'll never learn, she said, folding it. Go back to your books. But she smiled.'(TCR 80)

Alu proposes Maya Debnath to marry but she smoothly rejects his proposal and she says she has some responsibilities that is her brother's marriage. 'I can't married. Not now. Not till Rakhal marries.'(TCR 88) She is a silent sufferer. Her father and brother won't think about her pleasure. In one event Alu asks about her brother and father, both are every time in their own dreams. 'In Naboganj, she answered. And your father? She jerked her head at his hut. He's in there, I think, she said. Sleeping.' (TCR 91) At war time, Maya lost her house and the ear-rings and the two brass pots which were her only mementoes of her mother had vanished, too. Balaram gave shelter to her family at that time her condition is, 'Maya stumbled after him, blinded by her tears.'(TCR 131)

Later her father left her three days at Balaram's home. One day he get back and begged dinner to his daughter, '...Maya, he said urgently, in an undertone. Maya sighed with relief: it was three days since she had seen him last. $\mathrm{He}$ had come to the house, late one night, weak with hunger and asked for a handful of puffed rice. He would eat nothing more and, though she had begged him to stay, he had disappeared again that night.'(TCR 143-144) Rakhal involvs in many contradictions when he returns to his home Maya pleads him to stop all actions. 'Yes, kill us all, she said, we're all weapons - and went back to the house.'(TCR 155)

Parboti-debi is wife of Bhudeb Roy. She is there only for giving birth to children. 'And then, a couple of months later, someone spotted Parboti-debi, who had disappeared for a while, on the veranda of their house. She was unmistakably pregnant.'(TCR 105) She doesn't have any freedom in her own house. Her work is only to take care about her children and her family. 'She would not go. The delegation returned, disappointed, and nobody saw Parbotidebi again during her confinement.'(TCR 106)

Zindi assembles people to smuggle to al-Ghazira. She loses the vim and vigor that she has once possessed. She has been vibrant and assertive earlier but now, she just remains a mere shadow of her past. She desires to take possession of the Durban Tailoring House that belongs to Jeevanbhai Patel. The reason behind her 
wish is to provide the immigrants, with revenue sources. 'I can find any man a good job. And, as for women, why, when I go to India I don't have to do anything. These women find me and come running:' '(TCR 194) It shows her concern for the people of her country. 'Because I can give them food, I can give them a roof, but I can't give them work. When it comes to work, this house is like an empty crate people can kick it here, kick it there, and I'm helpless. That's why all this has happened - Mast Ram and Abusa; Professor Samuel and Kulfi losing their jobs.' (TCR 236)

She doesn't have any relatives in foreign land as well as in the native land. In their journey, Karthamma an unlucky lady gave birth to a boy child. Zindi takes the boy's (Boss) responsibility. She has saved baby Boss from war and feels he is the light of her life. '...Zindi came smiling up to the deck. She had a baby cradled in her arms.'(TCR 201) '... with the baby still in her arms, and we were running behind her.' (TCR 298) 'For Karthamma has a baby - the child Zindi was holding in her arms that night - and poor, childless Zindi treasured her for that alone; because she was a mother and because she had given her a son. If pure will could change flesh and blood, that baby would be more hers now than his mother's.'(TCR 299) 'At that Zindi stopped fighting, and clutched the boy to her chest.'(TCR 305) Zindi gave shelter to Alu because she was suspected as a terrorist by police.

Karthamma another character gave birth to a baby child in the middle of the shore. That is her unwanted pregnancy. She doesn't want to give any birth to a child because of identity and poverty. She is also smuggled by Zindi and asks her give satisfactory life to her child. 'You can tell as soon as you see her that she does eight-anna jobs in ricefields and things like that. And here she is, convinced that if she signs a form her baby will get cars and houses and all that. Where do these villagers get these ideas?' (TCR 190)

Kulfi is a beautiful widow. She joined as a chef in a rich Ghaziri's house. Because of an Indian woman she was suspected by her owner family. Because she lost her job. 'No, we're going, said the grandmother. I'm not going to eat food cooked by an Indian. Don't you remember how your uncle told us that these Indian women spit into the food because they like the flavor?'(TCR 219) Works also divided by gender. 'Outside, in the courtyard, Kulfi and Karthamma were cooking their usual morning meal of rice and fried potatoes on a mud oven. When the rice 
was done they carried the pots into Zindi's room and called out to the others. The women ate at one end of the room and the men at the other.' (TCR 230)

The third chapter begins in $\mathrm{El}$ Oued, a small town in the Algerian Sahara, with the introduction of a new character, Dr. Uma Verma. She is a microbiologist in a hospital. She and her house play a pivotal role in the novel. Alu, Zindi, Kulfi and Boss reach the place having escaped by the police of al-Ghazira who have helped the Indian ASP Jyothi Das who is appointed to track down Alu. Kulfi offered a character Chitrangadha in play. She involves herself in the character and feels she is really Chitrangadha. At that time Zindi warns her and explains what her real position is? 'Chitra...what? Zindi gasped. Listen, you bitch. Today you're no different from what you were when I first met you. You're Kulfi the small time callgirl whose MA-pass husband turned her to whoring when the lost his fancy job; you're palefaced, unemployed old Kulfi who came to me in Bangalore and said, Take me to al-Ghazira and give me some honest work.'(TCR 422) Kulfi, for whom there has been tears and blood, collapses during the rehearsal of Chitrangadha and breathes her last.
Mrs.Verma also insulted by her higher authorities 'No, we don't have a maidservant, and if you want one you should go back to India, Mrs Verma, instead of asking for my wife.' (TCR 382) She is a culture and tradition sufferer. After Kulfi passing away at Mrs.Verma's home, she is trying to follow tradition and culture in foreign land. Kulfi's body is burnt with the help of the dry wood, broken furniture and other things. Later, Mrs. Verma, to cleanse the area, sprinkles carbolic acid where the dead body of Kulfi has to be laid to rest.

\section{Conclusion}

Reason starts with Alu's arrive to Balaram's home in Lalpukur. Characters faced many struggles in their own lands because of the effect of war. Poor Indians have gone abroad in search of money. They enter with new dreams and colourful ideas to foreign land, fictitious village alGhazira. Woman is the sufferer of the cultural and tradition even in their own land of birth. Though woman faces many problems, she feels that is her responsibility and has done household tasks without show any impatience.

\section{Reference}

[1] Ghosh Amitav, The Circle of Reason, (New Delhi: Penguin Books India Pvt. Ltd, 2008) 


\section{[2] http://www.amitavghosh.com/circle} ofreason.html

[3] Arya Sadhana, Woman, Gender Equality and the State, (New Delhi: Deep \& Deep Publications Pvt. Ltd, 2000)

[4] Bijay Kumar Das, Postmodern Indian English Literature, Atlantic Publishers and Distributors, New Delhi. Introduction. 2006. 